\title{
Can We Keep Independent Hip-Hop Lowkey?: Using Content Analysis to Analyze Glocalization in Lowkey's Lyrics
}

\author{
Christopher Vito \\ Correspondence: Christopher Vito, Institutional Affiliation, University of California, Riverside, USA
}

Received: September 30, 2015 Accepted: October 14, 2015 Online Published: October 17, 2015

doi:10.11114/smc.v3i2.1150

URL: http://dx.doi.org/10.11114/smc.v3i2.1150

\begin{abstract}
Despite much literature on glocalization, independent hip-hop artist Lowkey has yet to be studied for his contributions to UK hip-hop. Through content analysis, this article examines Lowkey's lyrics to demonstrate how the process of glocalization is used to appropriate US hip-hop culture to address salient social issues both within the context of UK hip-hop culture and globally. Utilizing this approach, this article uncovers three themes: 1) addressing issues of capitalism both locally and globally, 2) expounding upon the notion of false consciousness and how it disproportionately hurts the masses, and 3) utilizing independent UK hip-hop to promote ideas of social change and revolution.
\end{abstract}

Keywords: lowkey, independent hip-hop, glocalization, capitalism, hegemony

Word Count: 5,270

\section{Introduction}

\subsection{Introducing the Issue}

It's been a long time coming...Too long, too long...It's been in the making a quarter century.

But it's here now, it's here now...If by time you hear this album, I'm not here you know why.

British independent hip-hop artist Lowkey released The Soundtrack to the Struggle in 2011. It was well received in the UK and charted \#1 on the iTunes UK Hip-Hop Album Chart as a follow-up to his non-charted album Dear Listener in 2009. The album illuminates on topics such as Western-European hegemony, the rise of consumer culture, and the meaning of terrorism. In particular, his music illustrates the importance of glocalization —or the ability of hip-hop culture to spread beyond the confines of its creation in New York and be appropriated by local communities to address and resist local and global issues. For example, Lowkey gained notoriety for his position on the conflict between Israel and Palestine, stating that the Gaza Strip has become a site of Israeli domination. On the track, Long Live Palestine (2011a), he urges listeners to take a stance advocating for Palestinian rights and ending warfare in the Gaza Strip.

His body of work, ranging from mixtapes such as Key to the Game in 2005 to collaborative albums such as Poisonous Poetry with Poisonous Poets in 2005, resulted in a prolific career spanning from the UK to other countries such as Canada and the United States. Despite making impacts to the political and social contours of the independent hip-hop community with his 2011 album, Lowkey decided to temporarily retire from hip-hop to pursue personal endeavors. The purpose of this paper is to use theories of glocalization to uncover the dominant themes within Lowkey's lyrics and document his contributions to the independent hip-hop community.

\subsection{Intellectual Contribution}

We contribute to the existing literature (Bennett 1999; Delamont and Stephens 2008; Mitchell 2000; Morgan and Bennett 2011) by illustrating how Lowkey's lyrics, which have not previously been studied, demonstrate the salience of glocalization in the hip-hop community. We find that there are three main ways in which Lowkey's lyrics engage in the process of glocalization. First, Lowkey's lyrics show how his music can appropriate elements of hip-hop culture to address issues of capitalism occurring in the UK and worldwide. Second, his lyrics illustrate how he can simultaneously address issues of false consciousness by the masses in the current economic and political system. He argues that the masses, both locally and globally, buy into the current system and even believe that it benefits them. Finally, his music concurrently addresses the issue of social change and revolution via the spread of independent hip-hop culture. 


\subsection{Outline}

The remainder of the paper is organized into four sections. The first section reviews the literature pertinent to the field of glocalization and critical hip-hop. The second explains the data and methods utilized in the study. This is followed by the results of our analysis and a conclusion.

\section{Literature Review}

Many scholars have pinpointed the origins of hip-hop to the 1970s in the South Bronx of New York (Alridge 2005; Chang 2005). The debate amongst scholars lies in the authenticity of hip-hop culture. Most, like Dyson (2010), focus on hip-hop culture revolving around African-American issues in the United States. Yet, Bennett (1999) has acknowledged the fact that Puerto Ricans and whites were also involved in the construction of hip-hop in New York. Harrison (2006) further explicates this position, stating that viewing hip-hop culture as a simple black-white dichotomy oversimplifies race relations and obfuscates the position of other minorities. Thus, various authors argue that only analyzing African American issues is a dangerous way of studying hip-hop culture, as it requires an analysis of those directly connected to the African Diaspora (Bennett 1999; Gilroy 1993; Harrison 2006; Mitchell 1996).

\subsection{Hip-Hop Glocalization}

The term glocalization, aptly defined as a process where homogenizing and heterogenizing intertwine at the level of local identities in an increasingly interconnected world, has been widely used in hip-hop literature to break down the black-white dichotomy limited to the US context (Bennett 1999; Delamont and Stephens 2008; Morgan and Bennett 2011). Following Lull (1995), the concept of glocalization argues against a narrow definition of globalization, stating that cultural products can be reworked to fit particular local contexts. Robertson (1995) further popularized the term in his analysis of the spread of religion. Authors such as Bennett (1999) have then taken this term further in their analysis of hip-hop culture. He describes instances of hip-hop being appropriated outside of the US globally into local contexts. For example, he demonstrates the importance of hip-hop culture for whites in the city of Newcastle, England to highlight the locally constructed nature of hip-hop.

Similarly, other authors have found the concept of glocalization appropriate in their analysis. Mitchell (2000) illustrates how hip-hop can extend beyond the English language in the US. He shows how hip-hop in Zimbabwe, Switzerland, France, Italy, and New Zealand that use other languages such as French and Italian to re-appropriate hip-hop culture to fit local circumstances. Here, this framework shows that hip-hop culture is not restricted to the local in the US but rather is relocated in different languages in various parts of the world through the process of glocalization. Delamont and Stephens (2008) also show that this process of glocalization is not limited to language and music, but can be useful in studying dances such as Capoeira as well. Although it has its origins in Brazil, Delamont and Stephens (2008) explain how it has spread out of Brazil into a worldwide forum since 1975.

Furthermore, literature has shown the particular importance of glocalization in the UK specifically. For example, Hesmondhalgh and Melville (2002) illuminate how hip-hop has been transmuted into UK culture and left lasting repercussions for UK hip-hop. They state that US produced hip-hop music has resonated with both black and white British youth. In particular, upon mediating hip-hop within UK identity they illustrate how a complex network of hip-hop culture ranging from Britain, the Caribbean, and the US has helped negotiate new ethnic identities amongst British Asian musicians. In addition, Dedman (2011) shows how the rise of Grime culture, which originated in the UK, has its roots in garage, dancehall, and hip-hop music. He notes that it is 'considerably faster than hip-hop (both in the US and UK), yet the vocal delivery is akin to rapping, mixing a style that is also reminiscent of Jamaican roasting' (Dedman 2011: 518).

\subsection{Hip-hop as a Site of Resistance}

Alridge (2005) states that hip hop emerged from social, economic, and political experiences of black youth in the 1970s. $\mathrm{He}$ argues that politically and socially conscious hip-hop is directly connected to the civil rights movement and the black freedom struggle. In essence, hip-hop's origins come from a social movement against the current system surrounding African Americans. But as previously stated, the process of glocalization re-appropriates this process globally. Thus, hip-hop can provide a means of resistance to domination through language and action outside of its original context in the US.

For example, authors (Decker 1993; Harrison 2006; Lin 2006; Mitchell 2003; Solomon 2005) have shown how appropriations of hip-hop culture have resisted mainstream corporate domination. Mitchell (2003) states that subcultural hip-hop in Australia still exhibits many of the "classic" features of youth subculture. For instance, they define themselves as "underground" in relation to mainstream music, as they maintain a subordinate and subaltern status. Similarly, Solomon (2005) looks at how hip-hop artists in Istanbul define themselves as underground. They transmute the globally circulating genre of hip-hop to construct an identity that is underground, in which they define underground 
hip-hop as music not released by commercial record companies which is embodied in terms of style and attitude (Solomon 2005).

In addition, Decker (1993: 59) points out hip-hop artists can act as organic intellectuals, a term coined by Gramsci, as they are directly linked to the everyday struggles and their music critically engages with the community in which they live. Being in a privileged position allows hip-hop artists to expound on issues such as capitalism and the privatization of hip-hop culture. As evidence, Harrison (2006) states that mix tapes produced and circulated in the Bay Area are subcultural artifacts that do embody progressive politics and defend against mainstream co-optation. Lin (2006) reinforces this position by stating that hip-hop subcultures have found a niche within the field of cultural production to critique the capitalist practices of the pop culture music industry. Specifically looking at artists in Hong Kong, Lin shows how these artists resist capitalist modes of production by capitalizing on new media technologies such as the internet, using indigenous words rather the language of the colonizers, and aligning with left leaning parties.

Finally, Delamont and Stephens (2008) state that hip-hop has its origins in grassroots movements. With the rise of glocalization, Morgan and Bennett (2011) contribute to this literature by discussing the rise of a global hip-hop culture that mediates the processes of glocalization with viewing hip-hop as a site of resistance to domination. They write that it is 'a culture that encourages and integrates innovative practices of artistic expression, knowledge production, social identification, and political mobilization. In these respects, it transcends and contests conventional constructions of identity, race, nation, community, aesthetics, and knowledge' (177). In essence global hip-hop has expanded around the world while simultaneously being transformed to fit local contexts, creating a new "third space" in which contestation can occur (Omoniyi 2006). As Androutsopoulos and Scholz (2003) state, this process is a recontextualization of cultural forms through the local appropriations of a globally acceptable cultural model that can lead to knowledge production and social movements.

\section{Methodology}

\subsection{Content Analysis}

The chosen methodology for this work is a content analysis of Lowkey's album Soundtrack to the Struggle. The album has twenty-six tracks, which include six skits, and spans ninety-five minutes. Content analysis was the ideal methodology because it provides an analysis that accounts for context and history that is mediated through language (Gadamer 1960; Metro-Roland 2010). An analysis of Lowkey's lyrics is strengthened when interpreted and analyzed as a medium of expression not divorced from their specific contexts of use (Vito 2014). Moreover, the use of content analysis has been previously used to analyze hip-hop lyrics (Shusterman 1992; Tickner 2008; Trapp 2005). Our analysis is unique in that Lowkey's album has not previously been analyzed despite being charted in UK and receiving critical acclaim from the hip-hop community.

\subsection{Unit of Analysis}

Our unit of analysis is bars, which is loosely defined as a line in a rap verse. For example, the line in Terrorist (2011b) 'They're calling me a terrorist...Like they don't know who the terror is' was used a bar. This approach has been previously used in a similar study analyzing Immortal Technique's lyrics (Vito 2014). The lyrics were obtained from www.rapgenius.com and were verified by the primary author. In cases where discrepancies occurred, the primary author revised the lyrics firsthand. The lyrics were then compared with other lyric websites to confirm accuracy and placed into Excel.

\subsection{Coding}

Further, the lyrics were coded by theme. The primary author coded the lyrics by theme, and the second author identified any discrepancies in the coding. This was used as a means of double-checking and verifying the codes, as well as allowing the second author to input anything that was missed. Initially, there were five main themes uncovered by the primary author: anti-capitalism, false-consciousness, intersectionality of race and gender, revolutionary ideas, and independent hip-hop culture. Upon verification with the second author, three themes emerged: the appropriation of hip-hop culture to address issues of capitalism, the use of hip-hop to illuminate issues of false consciousness, and how independent hip-hop culture can advocate for social change and revolution. These themes are further elaborated below.

\section{Analysis}

There are three main themes occurring in Lowkey's lyrics that exemplify the notion of glocalization. His lyrics also present a consistent theme of resistance through hip-hop. The three themes are presented below.

\subsection{Issues of Capitalism in the UK and Worldwide}

According to Bennett (1999), the process of glocalization appropriates hip-hop music originating in New York to various locations around the world. Alridge (2005) also argues that hip-hop can be used to express discontent with the 
current economic, social, political and cultural system in which the artists live. Lowkey's lyrics exemplify this concept as he takes components of hip-hop culture to address salient local and global issues relating to capitalism. For example, Lowkey writes in Soundtrack to the Struggle (2011c) that the UK is 'declared a republic, and ended (its) monarchy (but) your corporate dictatorship, pretends it's democracy'. He openly critiques the UK government as a false democratic system, and instead argues that it is dictatorship ruled under the premises of neoliberal capitalism. Also, he raps in Dear England (2011d):

Never will there be a day that cameras are turned off

Who runs this country, Cameron or Murdoch?

Who's the government, a government that can't govern

Can't you figure it's ways bigger than Mark Duggan

Bigger than Smiley, bigger than Jean Charles

Hundreds are dead not one killer is on trial.

In the preceding verse he questions the current economic and political system by asking if Prime Minister David Cameron or business mogul Rupert Murdock runs the country. He further questions if the government can effectively run the country if the courts favor a repressive police state and side with big business bankers. Ultimately, his lyrics demonstrate how hip-hop culture is used by Lowkey to address issues in the UK.

In addition, Lowkey's verses address Western hegemony and its effects on the rest of the world. In Obama Nation (2011e), he raps:

This track is not an attack upon the American people...It is an attack upon the system within which they live... Since 1945 the United States has attempted to overthrow more than 50 foreign governments...In the process the U.S has caused the end of life for several million people, and condemned many millions more to a life of agony and despair.

For Lowkey, he attributes US hegemony within a capitalist framework as the source of many countries' oppression. Despite being situated in the UK, his lyrics address how the US directly impacts other nations, as well as Lowkey himself. As he writes in Long Live Palestine (2011a), 'Obama promised Israel 30 billion over the next decade...they're trigger happy and they're crazy...think about that when you're putting Huggies nappies on your baby.' He reminds listeners in his rap that other countries outside the US are held hostage by policies made by the Obama administration. In essence, he writes from an outsiders' perspective to highlight how both the US endorses capitalist corporate dictatorship. In Terrorist (2011b), 'everyday USA - that is terrorism.'

Furthermore, Lowkey's lyrics address issues of globalization by arguing that neoliberalism has had a negative impact on the masses and the poor. He cites the underlying ideology of free markets for the growing disparity between the rich and the poor, as well as admonishing global organizations for upholding neoliberal policies. For instance, he writes in Soundtrack to the Struggle (2011c) 'I hold your bloodline, accountable for every crime...Adam Smith to Rothschild, it's all been a clever lie.' He begins his analysis by stating that the underlying ideology of the free market and the invisible hand underpin the neoliberal policies implemented by families that have obtained a fortune such as the Rothschild family.

More recently, he points out how neoliberal policies have helped major corporations. He raps in Hand on Your Gun (2011f), 'next in my scope is Lockheed Martin...They will tell you when the bombs need blastin'.' In his song, he understands the power of major corporations to use warfare to impose policies that benefit them. In the case of the war in the Middle East, corporations in the US (namely those linked to Dick Chaney and the Bush administration) profited from rebuilding infrastructure in Iraq. Finally, he acknowledges the importance of global organizations who serve the interests of the wealthy. He writes in Terrorist Part 2 (2011g) that 'we know the truth, no matter what you tell 'em on the television...IMF, World Bank, economic terrorism.' The IMF and World Bank play a large role in maintaining policies that support the current economic system. As Lowkey points out, this helps maintain the power of the capitalist class as it expands its ideologies into third world countries. Ultimately, Lowkey's lyrics exhibit glocalization by using hip-hop to analyze capitalism within the context of neoliberal globalization.

\subsection{False Consciousness by the Masses}

Morgan and Bennett (2011) argue that a key component of glocalization, and global hip-hop, is knowledge production. As Decker (1993) states, hip-hop artists who are organic intellectuals hold a privileged position to engage with their community about issues that are salient to them. They are further able to stimulate discussion and create knowledge. This production occurs locally within the context it occurs, but can simultaneously address global issues. As is the case with Lowkey, he embraces the critical side of hip-hop culture that demands listeners to reflect on their social positions in the world. He vehemently argues that the masses are being fooled into believing the current economic and political 
system benefits them. This is particularly true of people in Lowkey's own state. He writes that they buy into society's rules and lose because of it. For example, in Terrorist Part 2 (2011g):

And this is the part where the plot just gets sinister

They banned from the City of London and Westminster

I do this for the rebels that do this without the medals

For Smiley Culture, Jody McIntyre and Alfie Meadows

Before you throw it at me, have a look at your backwards book

Definition of terrorism, Columbus and Captain Cook.

The previous bars reflect the false consciousness among the masses in the UK. He begins the verse by stating that his politics, which attempt to call out injustices in the world, have caused him to be banned by the majority in places like London and Westminster. He continues to show that the masses often side with the dominant class even though they engage in violence, excessive force, and even colonization. Lowkey mentions specifically: 1) British artist Smiley Culture who was killed during a police raid on his home, 2) handicapped political activist Jody McIntyre who was dragged one hundred yards and beat with a baton, and 3) political activist Alfie Meadows who had brain surgery after being beat by police officers during a student protest. Mass media depicted these individuals to the masses as menaces to society who oppose dominant beliefs and ideas despite really advocating for equality and freedom.

Globally, Lowkey addresses the issues of false consciousness by arguing that the masses are fooled into believing that the system benefits them. He argues that this occurs through a complex process of negotiation between the powerful and the powerless in which the powerful enact both coercion and consent among the masses, and the masses willingly buy into the dominant social order. As Lowkey raps in Voice of the Voiceless (2011h), 'this is for every one of Saddam's Kurdish murder victims...and all the pure souls that never had the chance to speak.' He continues in Cradle of Civilization (2011i), writing 'bombings, occupation, torture, intimidation...A million dead people doesn't equal liberation.' In both songs he points out that many people in the Middle East have been murdered to maintain the current social order, and that those who may want to speak out have been silenced throughout history to maintain the current hegemonic order.

But more insidious is the technique of consent in which the masses willingly uphold the current system without resistance. For example, Lowkey writes in Hand on Your Gun (2011f) that 'don't think, just listen to the songs, keep dancin'...do they really want us to have our own brains... who do you think is really running Guantanamo Bay.' Supporting the argument of false consciousness, the dominant class maintains power by keeping the masses distracted while they construct society in their image. The masses are then fooled into being complicit in maintaining status-quo. Ultimately, he states that false consciousness hinders the masses, both locally and globally, and maintains hegemony by the ruling elite in our current society.

\subsection{Independent Hip-Hop and Revolution}

Harrison (2006) argues that the strength of hip-hop culture lies in its ability to create subcultural artifacts that elucidate ones' social biography. More importantly these subcultural artifacts can be appropriated in different contexts, while embodying progressive politics and defending against mainstream co-optation (Lin 2006; Mitchell 2003; Solomon 2005). Lowkey supports this argument, identifying how independent hip-hop in the UK can appropriate elements of hip-hop's origins to resist corporate domination and false consciousness. For example, he writes in My Soul (2011j) 'my integrity is the reason I'm thinking separately...keep your three-sixty I can do this independently.' Similarly in Blood, Sweat, and Tears (2011k) he raps:

I swear these major labels must think that I'm stupid

Keep your 360's you're convincing these dudes with

Like I'll give you the blueprint for pimping my music.

Hip-hop's origins were couched in the premise of rapping about social problems in a free, open space for African-Americans. Similarly, Lowkey appropriates this ideal in the UK by advocating for independent hip-hop artists not being controlled by 360 contracts by major corporations. This allows artists such as Lowkey to think and act independently rather than being corporate puppets.

Utilizing music as a means to freely express himself, he stresses the importance of not being used by corporations for capitalist domination. He writes in My Soul (2011j) that 'they can't use my music to advertise for Coca Cola...they can't use my music to advertise for Motorola...they can't use my music to advertise for anything.' Instead, he argues that independent hip-hop provides a site of resistance to fight domination. In Soundtrack to the Struggle (2011c), he points out that 'my music is my natural resource, now I want it back...til I sever every single chain I will not relax.' By every single chain, he reiterates his desire to bring down the capitalist structure that has weighed upon hip-hop from its 
inception to UK hip-hop in the present. Ultimately using the process of glocalization, he proposes to other artists that subverting meaning via hip-hop in the underground is possible (Potter 1995).

Finally, Delamont and Stephens (2008) state that hip-hop has its origins in grassroots movements. Within the framework of glocalization, Morgan and Bennett (2011) also argue that glocalization can exacerbate political mobilizations in local contexts. Similarly, Lowkey believes revolution is necessary to change the current hegemonic structure in which he lives. He envisions this revolution to have the goal of unity and equality. He writes in Cradle of Civilization (2011i) that 'this system of division makes it harder for you and me...peace is a question, the only answer is unity.' The problem for Lowkey then becomes how to mobilize in the current political environment to demand social change. Initially, he states that violence is necessary to resist domination. At one point, he even states that he has to keep his "hand on (his) gun." In Million Man March (20111), he supports this position by rapping that 'peace is something I would really adore....but we are at war so give me a sword.' Yet, at the conclusion of the track he writes that the pen is mightier than the sword, and determines that hip-hop and its ideas are more effective in mobilizing the masses. Like Dimitriadis (2009), Lowkey believes hip-hop's lyrics have become a powerful locus of social change because it can be created anywhere spontaneously and cannot be fully repressed.

\section{Conclusion}

\subsection{Summary}

Through content analysis, we have examined Lowkey's lyrics to demonstrate how the process of glocalization is used to appropriate US hip-hop culture to address salient issues both within the context of UK hip-hop culture and globally. Utilizing this approach, three themes were uncovered: 1) addressing issues of capitalism both locally and globally, 2) expounding upon the notion of false consciousness and how it disproportionately hurts the masses, and 3) utilizing independent UK hip-hop to promote ideas of social change and revolution.

\subsection{Weaknesses and Future Research}

One primary weakness of this study is the lack of firsthand data through interviews with Lowkey himself. Continued research needs to be done interviewing the artist, as well as further analysis of his lyrics outside of the album Soundtrack to the Struggle. In addition, future studies should document his relationship to social movements resisting globalization, US hegemony, and racism. Finally, this study should be expanded to incorporate other independent hip-hop artists associated with Lowkey such as Logic, Klashnekoff, and The Narcicyst.

\subsection{Contributions to the Literature}

Nonetheless, there are two important contributions to the literature. First, we contribute to the literature concerning hip-hop and critical pedagogy. Utilizing concepts such as glocalization, we see the salience of hip-hop as a tool for critical thinking. Lowkey's lyrics provide a space to discuss issues of social inequality both at the local and global level, while also creating a place for critical language creation, the transmission of cultural politics, and a third space for identity formation (Akom 2009; Alim 2007; Dimitriadis 2009; Potter 1995; Stoval 2006). Second, we remind readers that hip-hop culture is not divorced from political action, but rather artists' lyrics are reinforced through action (Decker 1993; Lin 2006; Omoniyi 2006). Lowkey's lyrics are not simply words on a paper, but are also embodied in actions such as membership in the Palestinian Solidarity Campaign and the Stop the War Coalition. He is also a known political activist and protestor. As Lowkey writes in Soundtrack to the Struggle, 'I knew the truth since I was a small little boy...I am a product of the system I was born to destroy.'

\section{References}

Akom, A. (2009). Critical Hip Hop Pedagogy as a Form of Liberatory Praxis. Equity \& Excellence in Education, 42(1), 52-66. http://dx.doi.org/10.1080/10665680802612519

Alim, H. (2007). Critical Hip-Hop Language Pedagogies: Combat, Consciousness and the Cultural Politics of Communication. Journal of Language, Identity \& Education, 6(2), 161-176. http://dx.doi.org/10.1080/15348450701341378

Alridge, D. (2005). From Civil Rights to Hip Hop: Toward a Nexus of Ideas. The Journal of African American History, 90(3), 226-252.

Androutsopoulos, J., \& Scholz, A. (2003). Spaghetti Funk: Appropriations of Hip-Hop Culture and Rap Music in Europe. Popular Music and Society, 26(4), 463-479. http://dx.doi.org/10.1080/0300776032000144922

Bennett, A. (1999). Rappin' on the Tyne: White Hip Hop Culture in Northeast England-an Ethnographic Study. The Sociological Review, 47, 1-24. http://dx.doi.org/10.1111/1467-954X.00160

Chang, J. (2005). Can't Stop Won't Stop: A History of Hip-Hop Generation. New York: St. Martin's Press. 
Decker, J. (1993). The State of Rap: Time and Place in Hip Hop Nationalism. Social Text, 34, 53-84. http://dx.doi.org/10.2307/466354

Dedman, T. (2011). Agency in UK Hip-Hop and Grime Youth Subcultures-Peripherals and Purists. Journal of Youth Studies, 14(5), 507-522. http://dx.doi.org/10.1080/13676261.2010.549820

Delamont, S., \& Stephens, N. (2008). Up on the Roof: The Embodied Habitus of Diasporic Capoeira. Cultural Sociology, 2(1), 57-74. http://dx.doi.org/10.1177/1749975507086274

Dimitriadis, G. (2009). Performing Identity/Performing Culture: Hip Hop as Text, Pedagogy, and Lived Practice. New York: Peter Lang.

Dyson, M. E. (2010). Know What I Mean: Reflections on Hip-Hop. New York: Basic Civitas.

Gadamer, H. G. (1960). Truth and Method. New York: Continuum.

Gilroy, P. (1993). The Black Atlantic: Modernity and Double Consciousness, London: Verso.

Harrison, A. K. (2006). Cheaper Than A CD, Plus We Really Mean It: Bay Area Underground Hip Hop Tapes as Subcultural Artefacts. Popular Music, 25, 283-301. http://dx.doi.org/10.1017/S0261143006000833

Hesmondhalgh, D. J., \& Melville, C. (2002). Urban Breakbeat Culture - Repercussions of Hip-Hop in the United Kingdom. In: Global Noise: Rap and Hip Hop Outside the USA, edited by Tony Mitchell. Wesleyan University Press.

Lin, A. (2006). Independent Hip-Hop Artists in Hong-Kong: Cultural Capitalism, Youth Subculture Resistance, and Alternative Modes of Cultural Production. Mobile and Popular Culture, 1, 1-18.

Lowkey. (2011a). Long Live Palestine. In: Soundtrack to the Struggle. England: Mesopotamia Music.

Lowkey. (2011b). Terrorist. In: Soundtrack to the Struggle. England: Mesopotamia Music.

Lowkey. (2011c). Soundtrack to the Struggle. In: Soundtrack to the Struggle. England: Mesopotamia Music.

Lowkey. (2011d0. Dear England. In: Soundtrack to the Struggle. England: Mesopotamia Music.

Lowkey. (2011e). Obama Nation. In: Soundtrack to the Struggle. England: Mesopotamia Music.

Lowkey. (2011f). Hand on Your Gun. In: Soundtrack to the Struggle. England: Mesopotamia Music.

Lowkey. (2011g). Terrorist Part 2. In: Soundtrack to the Struggle. England: Mesopotamia Music.

Lowkey. (2011h). Voice of the Voiceless. In: Soundtrack to the Struggle. England: Mesopotamia Music.

Lowkey. (2011i). Cradle of Civilization. In: Soundtrack to the Struggle. England: Mesopotamia Music.

Lowkey. (2011j). My Soul. In: Soundtrack to the Struggle. England: Mesopotamia Music.

Lowkey. (2011k). Blood, Sweat, and Tears. In: Soundtrack to the Struggle. England: Mesopotamia Music.

Lowkey. (20111). Million Man March. In: Soundtrack to the Struggle. England: Mesopotamia Music.

Lull, J. (1995). Media Communication, Culture: A Global Approach. Cambridge: Polity Press.

Metro-Roland, D. (2010). Hip-hop hermeneutics and multicultural education: a theory of cross-cultural understanding. Educational Studies, 46, 560-578. http://dx.doi.org/10.1080/00131946.2010.524682

Mitchell, T. (1996). Popular Music and Local Identity: Rock, Pop and Rap in Europe and Oceania. Leicester. Leicester University Press.

Mitchell, T. (2000). Doin' Damage in my Native Language: The Use of "Resistance Vernaculars" in Hip Hop in France, Italy, and Aotearoa/New Zealand. Popular Music and Society, 24(3), 41-54. http://dx.doi.org/10.1080/03007760008591775

Mitchell, T. (2003). Australian Hip-Hop as a Subculture. Youth Studies Australia, 22(2), 40-47.

Morgan, M., \& Bennett, D. (2011). Hip-Hop \& the Global Imprint of a Black Cultural Form. Dadalus: the Journal of the American Academy of Arts \& Sciences, 140(2), 176-196. http://dx.doi.org/10.1162/daed_a_00086

Omoniyi, T. (2006). Hip-Hop through the World Englishes Lens: A Response to Globalization. World Englishes, 25(2), 195-208. http://dx.doi.org/10.1111/j.0083-2919.2006.00459.x

Potter, R. (1995). Spectacular Vernaculars: Hip-Hop and the Politics of Postmodernism. Albany: State University of New York Press.

Robertson, R. (1995). Glocalization: Time-Space and Homogeneity-Heterogeneity . In: Global Modernities, edited by 
Featherstone, M., Lash, S. and Robertson, R. London: Sage. http://dx.doi.org/10.4135/9781446250563.n2

Shusterman, R. (1992). "Challenging conventions in the fine art of rap." In: That's the Joint! The Hip-Hop Studies Reader, edited by Forman M and Neal MA. New York: Routledge.

Solomon, T. (2005). Living Underground is Tough: Authenticity and Locality in the Hip Hop Community in Istanbul, Turkey. Popular Music, 24, 1-20. http://dx.doi.org/10.1017/S0261143004000273

Stoval, D. (2006). We Can Relate: Hip-Hop Culture, Critical Pedagogy, and the Secondary Classroom. Urban Education, 41(6), 585-602. http://dx.doi.org/10.1177/0042085906292513

Tickner, A. (2008). Aqui en el ghetto: hip-hop in Colombia, Cuba, and Mexico. Latin American Politics and Society, 50(3), 121-146. http://dx.doi.org/10.1111/j.1548-2456.2008.00024.x

Trapp, E. (2005). The Push and Pull of Hip-Hop: A Social Movement Analysis. American Behavioral Scientist, 48(11), 1482-1495. http://dx.doi.org/10.1177/0002764205277427

Vito, C. (2015). Who Said Hip-Hop was Dead? The Politics of Hip-Hop Culture in Immortal Technique's Lyrics. International Journal of Cultural Studies, 18(4), 395-411. http://dx.doi.org/10.1177/1367877914528529

\section{$(\mathrm{cc})$ EY}

This work is licensed under a Creative Commons Attribution 3.0 License. 